\title{
A TERRA INDÍGENA PÓ MÁG, TABAÍ/RS, NO CONTEXTO DAS MOVIMENTAÇÕES DE RETERRITORIALIDADE KAINGANG E BUSCA PELA GARANTIA DOS DIREITOS CONSTITUCIONAIS
}

\author{
Jonathan Busolli ${ }^{1}$
}

\begin{abstract}
Resumo: Os Kaingang são um grupo indígena pertencente ao tronco linguístico Macro-Jê que assim como os Xogleng fazem parte das populaçóes Jê meridionais, constituindo-se no terceiro maior grupo populacional indígena do Brasil. Seus tradicionais territórios distribuem-se originalmente pelos atuais estados de São Paulo, Paraná, Santa Catarina e Rio Grande do Sul, alcançando também a Província argentina de Misiones. Em contrapartida às políticas de expulsão de seus territórios praticadas pelo Estado brasileiro no decorrer do século XIX, os Kaingang protagonizam desde a segunda metade do século XX um processo de reterritorialidade, levando à criação de terras indígenas em regiôes localizadas em territórios das bacias hidrográficas do Taquari-Antas, Sinos e lago Guaíba, sendo a mais recente delas a Terra Indígena Pó Mág, localizada no município de TabaíRS. Este trabalho tem como objetivo analisar o processo de instalação da Terra Indígena Pó Mág no contexto das movimentaçóes migratórias Kaingang e seu protagonismo na busca pela garantia dos seus direitos constitucionais. Tomando por base aportes teóricos sobre territorialidade, cultura e educação indígena, aponta-se que o processo de instalação da Terra Indígena Pó Mág se deu no contexto das medidas compensatórias da duplicação da rodovia BR 386 destinadas às comunidades Kaingang atingidas direta ou indiretamente pelas obras, sobretudo devido às lutas empreendidas pelos Kaingang no sentido de garantir a continuidade de seus saberes tradicionais e pelo respeito a seus direitos constitucionais em relação ao acesso à saúde e a educação diferenciada, uma vez que, analisando-se o processo histórico, percebe-se que a sociedade não indígena envolvente impóe aos Kaingang suas próprias concepçóes organizacionais, sejam elas no âmbito social ou religioso, além de minimizar e marginalizar a presença indígena.
\end{abstract}

Palavras-chave: Kaingang. Reterritorialidade. Terra Indígena Pó Mág. Educação indígena. Saúde indígena.

Abstract: The Kaingang are an indigenous group belonging to the linguistic stem Macro-Je that as the Xogleng are part of the southern Jê populations, constituting the third largest indigenous population group in Brazil. Their traditional territories distribute up originally by the current states

1 Graduação em História Univates. Professor de História no colégio Cenecista Mario Quintana, Encantado-RS. 
of São Paulo, Paraná, Santa Catarina and Rio Grande do Sul, also reaching the argentine province of Misiones. In contrast to the expulsion policies of their territories implemented by the brazilian government in the nineteenth century, the Kaingang is starring in the second half of the twentieth century one repossession process, leading to the creation of indigenous lands in regions located in areas of the basins river Taquari-Antas, bells and lake Guaíba, the latest one being the Terra Indígena Pó Mág located in the municipality of Tabaí-RS. This work aims to analyze the process of Terra Indígena Pó Mág installation in the context of migratory movements Kaingang and its role in the search for the realization of their constitutional rights. Based on theoretical studies about territoriality, culture and indigenous education, points out that the process of Terra Indígena Pó Mág installation took place in the context of the compensatory measures of the highway duplication BR 386 intended to hit directly Kaingang communities or indirectly by works, mainly due to the struggles undertaken by Kaingang to ensure the continuity of their traditional knowledge and respect their constitutional rights in relation to access to health and differentiated education, since, by analyzing the historical process, it is clear that non-indigenous society surrounding imposes Kaingang their own organizational conceptions, whether social or religious context, in addition to minimizing and invisible-the indigenous presence.

Keywords: Kaingang. Repossession. Terra Indígena Pó Mág. Indigenous education. Indigenous health.

\section{Introduçáo}

Os Kaingang são um grupo indígena pertencente ao tronco linguístico Macro-Jê, e assim como os Xogleng, fazem parte das populações Jê meridionais. Segundo dados do Censo Demográfico de 2010 (IBGE, 2012), os Kaingang se constituem no terceiro maior grupo populacional indígena do Brasil, com uma população de 37.470 pessoas, sendo superados apenas pelos Guarani-Kaiowá ${ }^{2}$ e os Tikúna, com populações de 43.401 e 46.045 pessoas respectivamente. Seus tradicionais territórios são as áreas do planalto meridional brasileiro, cobertas por florestas de araucária, desde a bacia do rio Tietê no estado de São Paulo até as bacias hidrográficas do lago Guaíba, Sinos, Caí e Taquari-Antas no estado do Rio Grande do Sul e diferentemente de outras populações indígenas que viviam próximas a eles, só foram diretamente atingidas pelo contato com populações não indígenas a partir do século XIX, em um momento em que o recém-criado Estado nacional brasileiro buscava ocupar suas áreas de fronteiras com populações de origem europeia.

Este contato e o subsequente conflito gerado a partir dele originaram um processo de expulsão das populações Kaingang de seus territórios a partir da iniciativa estatal de confiná-los em aldeamentos. Nestes espaços, essas populações foram submetidas às tentativas de catequização e de formação de mão de obra agrícola barata para a economia local, práticas empreendidas pelo Brasil a partir das políticas indigenistas adotadas, independentemente dos regimes que o governaram, ao longo dos séculos XIX e XX.

2 Não confundir com os Guarani-M’byá, que habitam territórios nas regiões sudeste e sul do Brasil, assim como partes da Argentina, Uruguai e Paraguai. 
Mesmo com as políticas repressivas, as populações Kaingang jamais deixaram de circular por seus territórios e principalmente a partir da década de 1950, passam a empreender um processo de reterritorialidade sobre suas áreas tradicionais, estabelecendo terras indígenas em espaços agora ocupadas por contextos urbanos. No Vale do Taquari, Rio Grande do Sul, esse processo intensifica-se por volta da década de 1960, com o surgimento da Terra Indígena Jamã Tÿ Tãnh, localizada no município de Estrela.

Posteriormente outras sete terras indígenas surgiram, distribuídas em áreas da porção centro norte do Rio Grande do Sul. A mais recente destas terras indígenas é a Pó Mág, localizada no município de Tabaí, também no Vale do Taquari, instalada como medida compensatória às comunidades Kaingang da região e proximidades em virtude da duplicação 10 da rodovia BR 386, atingidas direta ou indiretamente pelas obras. A Terra Indígena Pó Mág surge então em uma área de terra nos arredores do município de Tabaí, onde se fixam Kaingang oriundos da Terra Indígena Foxá, sendo um desdobramento desta.

Considerando a perspectiva de historicidade dos próprios indígenas, este estudo busca apresentar aspectos relacionados ao contexto de surgimento da Terra Indígena Pó Mág e a atuação dos indígenas Kaingang neste processo e as demandas empreendidas pela comunidade na busca pelo acesso à saúde como, por exemplo, o atendimento médico e o acesso ao abastecimento de água e a uma educação diferenciada, conforme apresenta o texto constitucional de 1988, ao que tange ao direito das populações indígenas do Brasil.

O objetivo do trabalho, portanto, é apresentar o contexto da instalação da Terra Indígena Pó Mág como parte do processo de reterritorialidade Kaingang, além de identificar a importância das questões supramencionadas para a comunidade da Terra Indígena Pó Mág. A pesquisa tem como base metodológica o estudo qualitativo com análise de conteúdo e os procedimentos metodológicos contaram com a revisão bibliográfica e o levantamento documental e etnográfico a partir da presença na terra indígena, documentadas por meio da elaboração de diários de campo e da realização de registros fotográficos após a obtenção do Termo de Anuência Prévia (TAP) junto às lideranças da comunidade Kaingang. Também foram realizadas duas entrevistas com integrantes de agências oficiais, os quais assinaram o Termo de Consentimento Livre Esclarecido (TCLE) que garante resguardar sua identidade, motivo pelo qual neste estudo serão tratados com E1 e E2. Os dados obtidos na pesquisa são analisados com base teórica de autores como Clastres (1974 e 2014), Nobre (2005), Baniwa (2012), bem como Lappe e Laroque (2013).

\section{A Reterritorialidade Kaingang em espaços da Bacia Hidrográfica Taquari- Antas}

Há pelo menos quatro décadas do período atual iniciou-se o processo de reterritorialidade das comunidades indígenas do planalto rio-grandense para seus territórios tradicionais, principalmente os espaços localizados próximos a cidades 
de médio ou grande porte, na serra gaúcha, nos vales do Taquari e Sinos, bem como na região Metropolitana de Porto Alegre, não só transitando por esses espaços, algo que eles nunca deixaram de fazer, mas também se fixando em algumas destas áreas. Na região do Vale do Taquari, o início do retorno dessas populações se deu a mais quarenta anos por grupos Kaingang que lutam para manter em áreas deste território elementos de sua cultura e tradição (OLIVEIRA, 2010).

$\mathrm{Na}$ região são encontradas, atualmente, três terras indígenas Kaingang: a Terra Indígena Foxá, localizada no município de Lajeado, a Terra Indígena Jamã Tÿ Tãnh, localizada no município de Estrela e a Terra Indígena Pó Mág, localizada no município de Tabaí, a qual será enfocada no presente estudo. Na serra gaúcha encontramos a Terra Indígena Pó Nãnh Mág localizada no município de Farroupilha, na região Metropolitana de Porto Alegre encontramos as Terras Indígenas Morro do Osso/Tupeng Pó, Morro Santana e Fág Nbin e no Vale do Sinos a Terra Indígena Por Fi Gâ, em São Leopoldo. As referidas terras indígenas podem ser observadas no mapa (FIGURA 1).

Figura 1 - Mapa indicando as Terras Indígenas Kaingang em contextos urbanos no Rio Grande do Sul

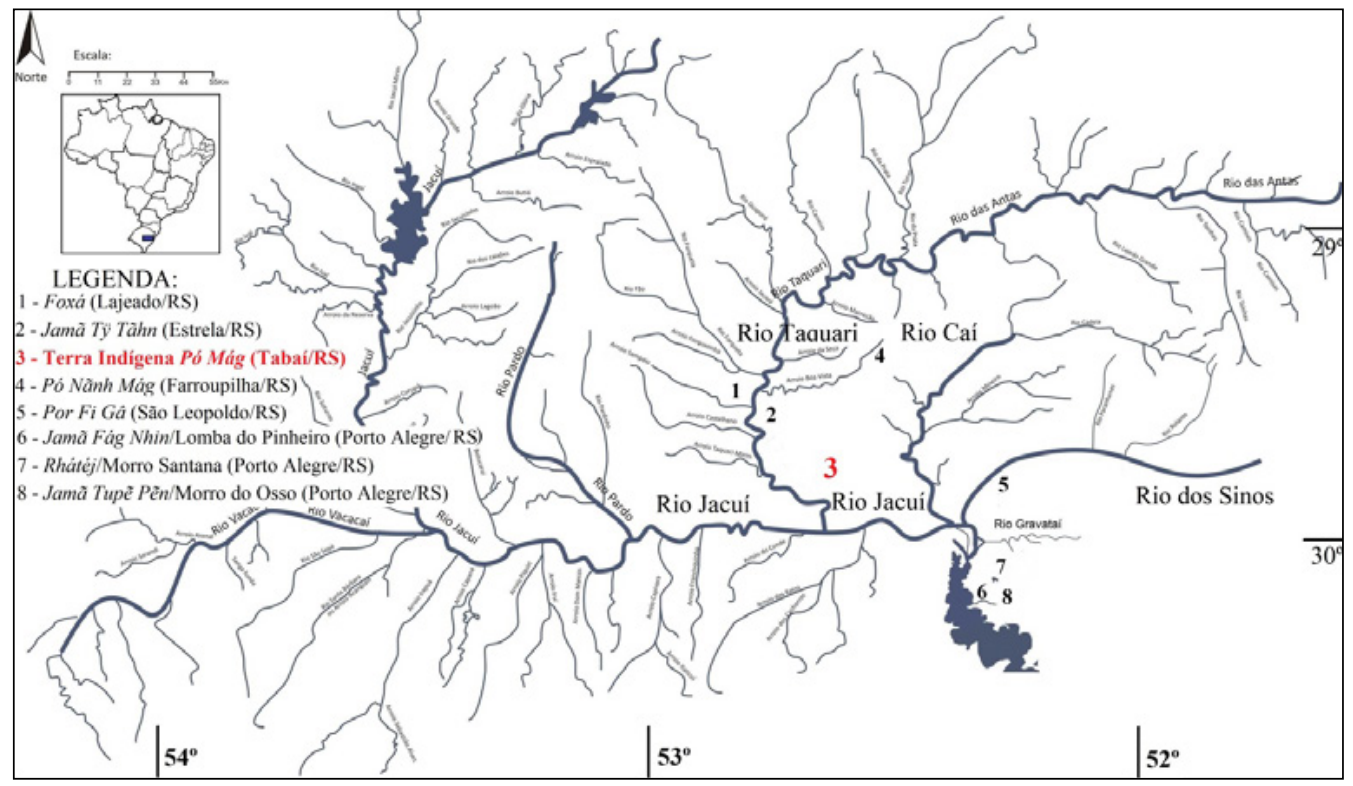

Fonte: Elaboração dos autores a partir do software SIG SEMA RS. Disponível em: <http:// enola.procergs.com.br/i3geo/aplicmap/geral.htm?m2c66daoa26om3829hr615am01>. Acesso em: 21/03/2016.

Segundo Lappe e Laroque (2013) a presença Kaingang em contextos urbanos visa a manter a sustentabilidade do grupo através da venda de seu artesanato, uma vez que os indígenas não conseguem, nos dias atuais, manter-se apenas com a agricultura de subsistência e com a coleta de produtos nas matas. Desse modo, os acampamentos provisórios erguidos tradicionalmente em áreas de coleta de 
provisões, denominados pelos Kaingang de wãre, passaram por uma atualização e desde então também podem estar localizados próximos às rodovias ou áreas urbanas, buscando por meio da venda do artesanato possibilitar o abastecimento econômico do grupo.

Esse processo de reterritorialidade empreendido pelos Kaingang sofreu desde o início resistência por parte da sociedade não indígena. No Vale do Taquari podemos apontar a desconfiança e o preconceito da imprensa local, que sempre viu a presença indígena na região como um problema, conforme atesta um trecho de reportagem veiculada pelo jornal "O Informativo do Vale" na década de 1970, presente a seguir:

$\mathrm{Na}$ semana que passou estiveram instalados em Cruzeiro do Sul, várias famílias de "bugres". Estes nômades passaram a ocupar as terras situadas nos arredores do novo campo de futebol do Cruzeiro F. C., no dia 13 deste mês. $\mathrm{O}$ ato de ocupação desta área foi efetuado sem pedido de licença da Prefeitura Municipal. Perguntado a respeito do assunto, o prefeito Paulo Ari Mallmann disse que não havia tomado conhecimento por encontrar-se na Capital do Estado. Afirmou, porém, que tomara as providências necessárias para a solução deste problema. No dia 15 , a caravana foi convidada a retirarse do local ao qual estavam assentados. A desapropriação aconteceu em virtude das pessoas que estavam residindo na área da Prefeitura, além de não possuírem nenhuma ocupação, praticarem atos visando a exploração da população cruzeirense [...] (BUGRES estiveram em Cruzeiro, 1978, p. 09).

A reportagem demonstra a permanente circulação dos Kaingang nas áreas de contexto urbano da bacia Hidrográfica Taquari-Antas. Essa presença indígena na região é tratada, na maioria dos casos, como um problema pela sociedade envolvente. Além disso, a sociedade não indígena busca muitas vezes, depreciar as populações indígenas em contextos urbanos, associando-as ao equivocado conceito de populações aculturadas, por estarem vivendo nas cidades. No entanto, os provedores e dispersores de tal discurso esquecem-se que não foram as populações indígenas que vieram aos espaços urbanos, mas que os espaços urbanos em sua não organizada expansão que avançaram sobre os tradicionais espaços das populações indígenas.

As cidades, no caso das regiões do Vale do Taquari e afins se constituem nas mesmas fronteiras étnicas que se formaram com o avanço não indígena no século XIX, e como dito em relação a essas fronteiras, elas existem para serem atravessadas. Diferentemente do discurso da aculturação, o contato com o outro não degenera a cultura do indivíduo, mas é a partir deste contato que se percebe como pertencente a um grupo específico. Algumas atualizações culturais podem ocorrer neste processo, mesmo assim, segundo Barth (2000), essas mudanças culturais que um grupo pode sofrer não afetam suas fronteiras étnicas, pois estas se encontram apoiadas nas diferenças com o outro, e por mais que a cultura possa ultrapassar as fronteiras, essa dicotomia entre grupos prevalece, garantindo a manutenção étnica cultural dos grupos. 
Esse "problema indígena", conforme apontado na reportagem anterior, fruto dos desencontros culturais dentro de uma fronteira étnica, vai ser maximizado a partir do ano de 2010, quando se inicia a duplicação da rodovia BR 386. A execução da obra atingiria diretamente a Terra Indígena Jamã Tü Tãnh, desse modo, conforme a legislação vigente, antes do início de qualquer obra, um estudo antropológico e ambiental deve ser produzido visando a avaliar os impactos que tal obra tende a acarretar.

No entanto, para a imprensa e sociedade local, havia por parte dos Kaingang uma tentativa de travar as obras de duplicação, e consequentemente o desenvolvimento econômico da região. Conforme aponta Faria (2014), o jornal "O Informativo do Vale", mesmo veículo jornalístico apresentado anteriormente, teve, ao longo do ano de 2014, uma postura sensacionalista e parcial em relação ao andamento das obras e a comunidade Kaingang afetada por estas, demonstrando um claro posicionamento contra a presença destes indígenas naquele espaço, o que reflete o pensamento da sociedade não indígena envolvente.

O primeiro desses Estudos de Impacto Ambiental/Relatório de Impacto Ambiental (EIA/RIMA) fora conduzido pelo Antropólogo Dr. Jaci Rocha Gonçalves (2008), contendo o contexto histórico, as condições de vida e as relações sociopolíticas da comunidade indígena em relação à sociedade envolvente, além das questões relacionadas ao impacto que as obras de duplicação da rodovia causariam não só aos indígenas Kaingang, mas também aos demais moradores estabelecidos às margens do trecho duplicado.

O laudo técnico sugeriu a aplicação de medidas compensatórias aos indígenas como meio de minimizar as perdas territoriais sofridas por eles. Dentre as medidas apontadas aos órgãos públicos para compensar os impactos aos Kaingang da Terra Indígena Jamã Tÿ Tãnh estão, por exemplo, a busca pela demarcação e oficialização da área como Terra Indígena; a criação de um grupo de trabalho para reunir e dialogar com os Kaingang das Terras indígenas próximas, bem como das terras indígenas Fág Nbin, Rhátéj, Tupeng Pó (Porto Alegre), Por Fi Gâ (São Leopoldo), e Pó Nãnh Mág (Farroupilha); a implementação de programas de apoio para sua sustentabilidade e autonomia da comunidade, a regularização, construção de moradia, banheiro, água e saneamento; a reforma e construção de uma escola, um posto de saúde e um centro cultural na comunidade (GONÇALVES, 2008).

Um segundo laudo antropológico fora produzido, agora desenvolvido por Ledson Kurtz de Almeida e Ricardo Cid Fernandes (2010), ambos doutores em antropologia. Neste outro laudo, seus responsáveis apontam uma série de objetivos e metas a serem alcançados em relação à comunidade, como a construção de novas casas para os Kaingang e a construção de uma escola. Também afirma que para o sucesso no que diz respeito às medidas compensatórias deveria haver a aquisição de 33 hectares de terra a serem distribuídos à comunidade de Estrela e outros 17 hectares a serem distribuídos para cada uma das seis comunidades Kaingang mencionadas no laudo anterior. 
Seguindo o que propunha o novo EIA/RIMA, no ano de 2013, após consulta a liderança Kaingang da Terra Indígena Foxá da época, o cacique Francisco Rockã dos Santos, uma área terra fora escolhida por ele e pelo restante do grupo para ser repassada à comunidade. Desse modo, surge a Terra Indígena Pó Mág, em Tabaí, como um desdobramento da Terra Indígena Foxá, representando uma medida compensatória em razão da duplicação da BR 386, que atinge esta última comunidade de forma indireta.

Desdobramentos e dissidências são fatores comuns entre as sociedades indígenas, entre elas os Kaingang. Segundo Clastres (1979 e 2014), isso acontece, pois as sociedades indígenas são caracterizadas por um movimento centrífugo, diferentemente das sociedades com Estado e seu movimento centrípeto, uniformizador. O movimento centrífugo das sociedades tradicionais é o meio das sociedades tradicionais se afastarem da centralização do poder a partir do afastamento de membros do grupo que ameacem o status quo, fazendo com que as formações de novos grupos a partir de um primeiro entre comunidades indígenas seja algo comum, sendo para o autor, um mecanismo que impede a formação do Estado entre as sociedades indígenas.

Entre os Kaingang, dissidências ou desdobramentos entre as lideranças foram comuns durante o século XIX, conforme apresentado por Laroque (2009). Outro exemplo desse tipo de movimentação na atualidade pode ser ilustrado a partir do desdobramento da Terra Indígena Jamã Fág Nbin/Lomba do Pinheiro que deu origem à Terra Indígena Jamã Tupe Pẽn/Morro do Osso, como vimos anteriormente.

\section{A Terra Indígena Pó Mág/Tabaí no Vale do Taquari}

O nome Pó Mág tem origem na língua Kaingang e significa "Pedra Grande", uma referência às inúmeras formações rochosas presentes no local. A Pó Mág fora inicialmente pensada como um wãre, acampamento provisório, para abastecer a Terra Indígena Foxá com matérias primas para a produção de artesanato. No entanto acaba por se transformar em um acampamento fixo ou emã (DIÁRIO de Campo, 08/01/2014). A sustentabilidade da comunidade também depende da venda do artesanato, realizado nos municípios próximos de Lajeado e Montenegro ${ }^{3}$.

Segundo o Procedimento Preparatório no 1.29.000.002074/2014-11 do MPF (BRASIL, 2014), a aquisição da área de 11,6 hectares, conduzido pelo DNIT, fora concluído em maio de 2013 com o repasse de $\mathrm{R} \$$ 640.000,00 ao seu proprietário João Alfredo Meurer, em três parcelas, de R $\$ 130.000,00, \mathrm{R} \$ 500.000,00$ e a última de $R \$ 10.000,00$, valor que pode ser considerado acima da média, uma vez que a quase totalidade da área está localizada em um declive acentuado. Localizada às

3 CULTURA da sobrevivência: Indígenas que estão pelas ruas são protegidos por lei. Fato Novo, Montenegro-RS, 07 de out. de 2015. 
margens da BR 386, a 2 quilômetros do centro do município de Tabaí, esta Terra Indígena surge no ano de 2013.

A primeira família a fixar-se na Pó Mág fora a do cacique Francisco Rockã dos Santos, que em fins de 2013 e a partir do referido momento passa a atuar simultaneamente como liderança Kaingang na Terra Indígena Foxá e Pó Mág. Nascido na Terra Indígena Nonoai, Francisco Rockã foi uma proeminente liderança Kaingang no Rio Grande do Sul e esteve presente no processo de lutas e movimentos de reterritorialidade Kaingang para áreas além do planalto. Segundo Aquino (2008), Francisco e sua família deslocam-se para essas regiões que incluem o Vale do Taquari, Vale dos Sinos e região Metropolitana no início dos anos de 1990 e entre idas e vindas para o planalto, participa ativamente da fundação das aldeias Morro Santana e Por Fi Gâ.

A área de terra correspondente a atual Terra Indígena Pó Mág, tratavase anteriormente de uma residência de verão para seu antigo proprietário não indígena. Neste local, aproveitava-se a não ocupação da terra para a plantação de árvores de acácia e eucalipto, cultura muito presente na região. Em visita a terra indígena em janeiro de 2014, o cacique Francisco relatou seu desejo por substituir aquela plantação por árvores frutíferas (DIÁRIO de Campo, 08/01/2014).

Os primeiros meses após a instalação da Terra Indígena Pó Mág foram marcados pela luta Kaingang no sentido de ver sendo cumprido os seus direitos assegurados com a Constituição de 1988. Conforme Diário de Campo (08/01/2014), as escolas do município de Tabaí não aceitaram matricular as crianças Kaingang, afirmando que estas não eram moradoras do município, algo também alegado pelo posto de saúde local, que negou atendimento médico aos Kaingang inicialmente. Tal situação necessitou de intervenção da FUNAI que no Oficio n ${ }^{\circ}$ 615/2014/ PRES/FUNAI-MJ (OFÍCIO, 2014b), informava a existência desta nova terra indígena, oriunda da Terra Indígena Foxá de Lajeado, e alertava a municipalidade de Tabaí sobre os direitos das populações indígenas quanto à saúde e educação e recursos disponíveis para garantir essas questões.

Conforme nos referimos, apenas 11,6 dos 17 hectares referentes às medidas compensatórias foram passados à Terra Indígena Pó Mág, portanto, há ainda 5,4 hectares para serem repassados. Em outra visita a terra indígena, conhecemos um sítio arqueológico localizado próximo a aldeia. O sítio consiste em um abrigo sob uma rocha, ideal para se abrigar da chuva. No local ainda há marcações de prospecções e a existência de petróglifos, entretanto, o cacique Francisco não soube responder a que grupo pertencia àqueles vestígios (DIÁRIO de Campo, 20/05/2014).

Segundo o cacique Francisco, os Kaingang buscavam junto ao Departamento Nacional de Infraestrutura de Transportes (DNIT) e a Fundação Nacional do Índio (FUNAI), a aquisição desta área onde está presente o sítio arqueológico para serem somados aos 11,6 completando os 17 hectares aos quais eles têm direito como medidas compensatórias. Segundo a liderança, caso essa aquisição venha a acontecer, os Kaingang da Terra Indígena Pó Mág planejam criar um roteiro 
turístico no local e aproveitar o possível fluxo de pessoas para buscar gerar divisas através da venda do artesanato (DIÁRIO de Campo, 08/01/2014).

Conforme o Estudo de Impacto Ambiental - Volume II, organizado por Alexandre Rosa (2011), o sítio arqueológico encontra-se nas coordenadas UTM 22J0429708/6716871 está bem preservado, porém há alguns problemas relacionados à erosão da estrutura rochosa e a depredação por parte dos visitantes. O estudo não fornece uma conclusão sobre qual tradição arqueológica deixou tais registros e enfatiza que a área tem relevância para ser estudada de forma mais aprofundada.

Segundo Diário de Campo (18/09/2015), a Terra Indígena Pó Mág contava até então com uma população de seis famílias, vivendo nos 11,6 hectares da área. A partir do protagonismo de suas lideranças, vem buscando manter a cultura e a sustentabilidade indígena nessa nova comunidade, assim como garantir à sua população os direitos que lhe são garantidos, como saúde e educação. Nesse caminho houve alguns percalços como a morte do cacique Francisco Rockã, ocorrida no dia 17 de agosto de 2015, vítima de um câncer no pulmão. Desse modo, a nova liderança, Tomé Fongue, busca dar continuidade à luta Kaingang e a obra de Francisco pela Terra Indígena Pó Mág.

Percebe-se dessa maneira que, desde o contato com o não indígena a partir das frentes de expansão no século XIX, os Kaingang vem lutando pelos seus direitos, sobrevivendo aos mais variados ataques perpetuados pela sociedade envolvente aos seus costumes e modo de ser. As políticas de cunho indigenista adotadas pelo Estado brasileiro desde sua formação sempre vieram no sentido de contribuir para o desaparecimento das populações indígenas, impedindo-os de circular pelos seus tradicionais territórios, minimizando-os e invisibilizando-os.

No entanto, a partir do processo de reterritorialidade Kaingang empreendido a partir da segunda metade do século XX percebe-se a luta e o empenho dessa população na busca pelos seus direitos constitucionais e a afirmação de suas identidades étnicas. Entre as terras indígenas surgidas nesse processo, a mais recente, a Terra Indígena Pó Mág vem lutando para se consolidar em meio ao preconceito e desconfiança da sociedade envolvente, empregando seu protagonismo nas suas demandas por saúde e educação que levem em consideração sua identidade, conforme garantido pela Constituição de 1988.

A inserção indígena em um processo de educação inerente a civilização ocidental, desenvolvido em um espaço próprio que é a escola, iniciou-se desde a chegada do não indígena ao continente americano. Não se pode negar o papel desenvolvido pela educação e pela escola no processo de conquista destas populações, uma vez que estes contribuíram para a inserção de valores morais inexistentes entre os indígenas. No entanto, mesmo que inicialmente pensado como meio de "civilizar" os indígenas, hoje a escola é vista por estas populações como ferramenta de luta na obtenção e manutenção de seus direitos, conforme segue:

A escola desempenhou na comunidade indígena duas funções sociais contrárias: em um primeiro momento foi uma forma de contribuir por meio 
da educação para sua integração nacional, e, em um segundo, assumiu papel adverso quando foi utilizada para revitalizar e fortalecer a cultura que the foi negada (SALVARO, 2012, p. 151).

Segundo Baniwa (2012), pode-se dividir a educação indígena no Brasil em dois momentos distintos. O primeiro é a educação escolar colonial de caráter integracionista, autoritária, paternalista do período anterior à promulgação da atual constituição brasileira no ano de 1988. A partir de então, inicia-se o segundo momento, onde há a busca pela implantação de uma escola indígena autônoma com o objetivo de fortalecer as identidades e culturas destes povos, bem como garantir seus direitos ao território, saúde, autonomia e o acesso aos conhecimentos científicos da sociedade moderna. Segundo o referido autor, neste segundo momento, percebe-se o aumento da procura de escolas por estudantes indígenas em todos os níveis de ensino, demonstrando uma nova postura destas populações em relação ao ensino escolar, já que até os anos finais da década de 1970, estes se mostravam ainda muito desconfiados sobre a importância da instituição escola.

Ao longo destes cinco séculos de encontros interétnicos na América, diferentes projetos de educação voltada para a "civilização" dos indígenas foram implantados por instituições não indígenas. Segundo Nobre (2005), as primeiras tentativas de implantação de um projeto educacional indígena deram-se através dos padres jesuítas que permaneceram no Brasil de 1549 a 1759, assim como de outras ordens da Igreja Católica, que visavam à pacificação por meio da cristianização com o objetivo de transformar as populações indígenas em mão de obra para o projeto colonial. Esse processo no sul da América meridional aconteceu através das chamadas missões jesuíticas, concentradas ao longo da zona fronteiriça entre as coroas portuguesa e espanhola, no norte da colônia brasileira a partir da foz do rio Amazonas e na região da bacia do rio da Prata, onde se conseguiu catequizar grandes quantidades de indígenas Guarani, sem obter o mesmo sucesso em relação às populações Jê, como visto anteriormente.

Segundo Nobre (2005), o projeto colonial de civilizar as populações indígenas a partir da expulsão dos jesuítas pode ser dividido em duas fases distintas, a fase "pombalina" e a fase que engloba o período monárquico e o início do período republicano até a década de 1980. Na fase "pombalina", alguns projetos foram postos em prática como a criação de duas escolas públicas para todas as povoações, uma reservada aos meninos que ensinaria a doutrina cristã, ler e escrever, e a outra destinada às meninas que além do aprendizado reservado aos meninos, também ensinava as atividades próprias do sexo feminino, segundo pensamento corrente na época.

A segunda fase, iniciada com a formação do Estado nacional brasileiro a partir do regime monárquico, é marcada pelo início do contato entre indígenas e não indígenas nas zonas de fronteira a partir do avanço das frentes de expansão, entre elas a imigração. Os conflitos e a subsequente adoção de projetos de aldeamentos indígenas que ocorreram na então província de São Pedro do Rio Grande do Sul, contaram inicialmente com o auxílio e administração de padres jesuítas radicados 
nos países vizinhos, principalmente Argentina e Uruguai, e por um curto período de tempo pelos padres capuchinhos, entre 1852 e 1854, conforme visto em capítulo anterior (NONNENMACHER, 2000).

O modelo de educação implantado nesses aldeamentos previa a prática da separação por faixa etária, afastando do convívio das crianças as pessoas mais velhas, algo que como já exposto, é o cerne da concepção de educação entre os Kaingang. Ou seja, era uma educação tradicional, rígida e cartesiana, sendo pouco atrativo para os indígenas em questão, conforme segue:

[...] toda vez que os padres missionários tentavam aplicar métodos rígidos do tipo tradicional da civilização europeia, eles se afastavam, não comparecendo mais nas escolas. Com os anos, o governo provincial ainda insistia na necessidade de instruí-los nas primeiras letras, o que não foi correspondido, pois assim como a religião, a tarefa de aprender a ler e a escrever também não foi bem aceita entre os índios (NONNENMACHER, 2000, p. 46).

Com a proclamação da república e a criação do Serviço de Proteção aos Índios e Localização dos Trabalhadores Nacionais (SPILTN) em 1910, posteriormente Serviço de Proteção aos Índios (SPI), no que diz respeito à educação, foi oficializado o ensino primário nas aldeias, a qual deixava de ser uma função do clero e passava a ser uma atribuição do estado. Segundo Bringmann (2012), a política indigenista brasileira pode ser apontada a partir de então pela tentativa de fomentar entre essas populações a adoção da educação e valores culturais ditos modernos, através da nacionalização e da busca pelo progresso econômico a partir da agricultura, o que envolvia a presença de espaços escolares nas aldeias, conforme segue:

[...] A partir da criação do Serviço de Proteção ao Índio e Localização dos Trabalhadores Nacionais (SPILTN), em 1910, os gentios foram colocados sob a tutela do Estado, que desde o advento da República passou a atuar de forma mais incisiva para territorializar, civilizar e integrar os povos indígenas na chamada sociedade nacional. Em cada "reserva" indígena, um posto do SPI, e em cada posto, uma escola [...] (BERGAMASCHI; MEDEIROS, 2010, p. $57-58)$.

Retomando novamente o estudo de Bringmann (2012), sabe-se que nestas escolas, os alunos indígenas eram induzidos a esquecer de suas tradicionais práticas agrícolas, passando a cultivar legumes e verduras. Ferramentas e instrumentos agrícolas eram repassados aos alunos, além de materiais didáticos, distribuídos apenas para as escolas que apresentassem bons resultados em relação ao ensino agrícola.

Neste processo de "escolarização indígena", Matte (2009) aponta que o SPI, já em seus primeiros anos de existência, é responsável pela instalação da primeira escola Kaingang no Rio Grande do Sul, localizada no Posto Indígena de Ligeiro, no município de Charrua. A instalação de escolas em área indígenas prosseguiu ao longo das décadas de 1920 e 1930 e ampliadas durante os governos do presidente 
Getúlio Vargas $(1930-1945)^{4}$, sendo parte do projeto de nacionalização implantado por ele.

Segundo Gonçalves (2011), em meados da década de 1950 fora firmado uma parceria entre o Estado brasileiro e o Summer Institute of Linguistics ${ }^{5}$ (SIL), instituição linguista de orientação cristã. Essa parceria foi estabelecida com o intuito de alfabetizar as populações indígenas em suas próprias línguas. O SIL utilizava metodologias e técnicas consideradas ultrapassadas pelos centros acadêmicos de renome, mas que no Brasil continuavam a ser utilizados com a mesma carga do pensamento colonizatório, na perspectiva de que a língua nativa das populações indígenas não deveria ser negada, mas sim "domesticada". Com o início das atividades do SIL fora criado a função de "monitor bilíngue", cujo objetivo nada mais era o de conceber um indígena domesticado e subalterno.

Matte (2009) salienta que através de uma parceria do SIL com a Igreja Evangélica de Confissão Luterana do Brasil (IECLB), que já fazia experimentos na área da educação indígena a partir de uma escola fundada em 1961 na então Reserva Indígena de Guarita, iniciou-se no ano de 1970 a primeira escola de formação bilíngue. Trata-se da Escola Normal Clara Camarão que posteriormente fora denominada de Centro de Treinamento Profissional Clara Camarão, localizada também em Guarita e que ao longo da década de 1970 formou três turmas de monitores bilíngues.

Esses monitores bilíngues acabaram servindo de informantes para os missionários na tarefa de tradução da bíblia, que seria o objetivo principal do SIL. Em função dessas ações, as línguas maternas das comunidades indígenas, conforme Gonçalves (2011) foram sendo reduzidas apenas ao âmbito do convívio familiar uma vez que a língua indígena não era aceita nas questões públicas, jurídicas, administrativas e comerciais, tornando-se inadequada aos seus próprios usuários.

No ano de 1973, o Ministério do Interior, promulga a Lei $\mathrm{n}^{\circ} 6.001$ que assegura as populações indígenas, o emprego da língua nativa juntamente com o português, cujo objetivo era buscar uma melhor integração entre essas populações e a sociedade nacional envolvente (BERGAMASCHI; MEDEIROS, 2010). Pode-se perceber que a partir dessas iniciativas, mesmo repleto de controversas, iniciou-se um processo de implantação de uma educação indígena diferenciada, intercultural ${ }^{6}$ e principalmente bilíngue, que segundo Baniwa (2012), emerge na década de 1970 e solidifica-se com a Constituição Federal de 1988.

4 Utiliza-se o termo "governos" no plural, pois se entende este período de quinze anos dividido em três fases distintas: o período que se estende de 1930 - 1934, marcado pela ausência de uma constituição federal, o período de 1934 - 1937, governo constitucional regido pela Constituição de 1934 e o Estado Novo, abarcando os últimos oito anos, de 1937 - 1945, da chamada Era Vargas. O presidente Getúlio Vargas voltaria a assumir o mais alto cargo do executivo brasileiro uma vez mais entre 1950 - 1954.

5 Conhecida em português por "Sociedade Internacional de Linguística".

6 Aqui entendido como interação entre duas ou mais culturas. 


\subsection{O Protagonismo da Terra Indígena Pó Mág pela garantia de acesso à saúde e educaçáo}

A Constituição Federal de 1988 representa um marco, pois é um grande avanço em relação aos direitos indígenas. Conforme Matte (2009) é a primeira vez no Brasil que se tem uma regulamentação jurídica nas relações entre o Estado e as populações indígenas contemporâneas, sobretudo assegurando a elas escolas específicas, diferenciadas, intercultural e bilíngue, características reafirmadas pela Lei de Diretrizes e Bases da Educação Nacional lançada em 1996.

No entender de Baniwa (2012), a partir da nova constituição, a forma de tratar as políticas indígenas passou a ser vista diferente do modelo tutelar e integracionista que se baseava na concepção de incapacidade das populações indígenas de decidir sobre sua própria vida e destino. Segundo o referido autor, a partir daí as questões relacionadas às políticas educacionais indígenas no Brasil seguiram três caminhos. O primeiro diz respeito ao estabelecimento de uma estrutura jurídica e normativa que visa a garantir autonomia pedagógica e de gestão aos povos indígenas. $\mathrm{O}$ segundo segue no sentido do reconhecimento de que o protagonismo indígena deve se fazer presente nessa área através do surgimento de professores e técnicos indígenas e o reconhecimento nas esperas políticas e jurídicas do direito coletivo das populações indígenas a uma educação especifica e diferenciada, e por último, o reconhecimento de que este processo deve ser seguido a partir da atuação destas populações como sujeitos históricos.

A nova escola indígena passou por alguns questionamentos no sentido de estabelecer quais demandas seriam levadas a primeiro plano, sendo preferencialmente levadas em consideração as questões inerentes à revitalização e valorização das culturas, das tradições e dos valores próprios de cada grupo, além de fornecer acesso ao conhecimento moderno. O grande desafio seria o de equacionar essas duas questões de forma razoável, equilibrada e coerente e, sobretudo, de como colocar isto em prática. Desse modo, a educação indígena deve levar em consideração as concepções e processos próprios desses grupos, contemplando a memória, a história, a tradição e os saberes ancestrais (BERGAMASCHI; DIAS, 2009).

No estado do Rio Grande do Sul há, desde a década de 1990, iniciativas de formação de professores bilíngues por parcerias entre instituições universitárias federais, a FUNAI e ONGs, algumas delas ligadas a instituições religiosas (MATTE, 2009). Segundo dados presentes no site ${ }^{7}$ da Secretaria de Educação do Rio Grande do Sul e referentes ao ano de 2014, há atualmente 83 escolas indígenas no estado, a maioria delas localizadas em terras indígenas demarcadas Kaingang e Guarani. Já no cenário nacional, Baniwa (2012) aponta que há atualmente 2.422 escolas em

7 ESTATÍSTICAS da Secretária Estadual de Educação do Rio Grande do Sul. Disponível em: $<$ http://www.educacao.rs.gov.br/pse/html/estatisticas.jsp?ACAO=acao1> Acesso em: $26 / 11 / 2015$. 
terras indígenas, onde trabalham 11.936 professores, sendo $90 \%$ deles indígenas. Essas escolas recebem 174.255 alunos que pertencem a mais de 240 etnias.

Dois importantes projetos que abarcam direta ou indiretamente as populações indígenas no âmbito da educação foram aprovados nos últimos anos. A Lei $\mathrm{n}^{\circ} 11.645 / 2008$ que torna obrigatório o ensino da história e cultura indígena e africana nas escolas é tratada como uma conquista no âmbito da educação indígena, pois aproxima as escolas não indígenas das lutas vividas pelos povos americanos (BRASIL, 2008), e a lei de criação dos territórios etnoeducacionais, ocorrida através do Decreto no 6861/2009, assinado pelo ex-presidente Luís Inácio Lula da Silva (2003 - 2010), que tem como objetivo central a necessidade de aprofundar o que dita o artigo 231 da Constituição Federal de 1988 no sentido de pôr em prática o reconhecimento das diferenças etnoculturais e da continuidade sócio histórica das populações indígenas (BRASIL, 2009).

Percebe-se desse modo que houve avanços no que diz respeito à educação indígena após a Constituição Federal de 1988. A escola indígena vem se consolidando como ferramenta de luta para essas populações no sentido de poderem dialogar de igual para igual com a sociedade nacional em busca da manutenção de seus direitos. Além disso, o bilinguismo é fundamental para que a escola sirva, além de ferramenta de diálogo, também como meio de manutenção cultural dos grupos indígenas.

Das três áreas indígenas Kaingang localizadas em territórios da bacia hidrográfica Taquari-Antas, apenas a Terra Indígena Jamã Tj̈ Tãnb/Estrela possui, neste momento, uma escola indígena oficial dentro de suas cercanias, denominada de Escola Estadual Indígena Manuel Soares. Este estabelecimento de ensino surge a partir da luta empreendida pela comunidade desde o início dos anos 2000, quando os Kaingang, após quase quatro décadas de invisibilidade por parte da sociedade envolvente, alcançou junto à FUNAI o status de "Terra Indígena" (SILVA, 2011). Atualmente, um novo prédio para abrigar a escola Manoel Soares está sendo construído, sendo a obra parte das medidas compensatórias referentes à duplicação da BR 386.

Na Terra Indígena Foxá/Lajeado, conforme Gonçalves (2011), as crianças da comunidade estudam na escola não indígena Escola Estadual de Ensino Fundamental Manuel Bandeira, localizada no bairro Florestal de Lajeado. Recentemente houve por parte da comunidade a instalação de uma escola improvisada dentro terra indígena (DIÁRIO de Campo, 08/07/2014). A escola indígena da Foxá foi criada através do parecer no 665/2012, decreto no 49.646, de maneira emergencial enquanto não se resolvem as questões relacionadas à área de terra ocupada pela comunidade, sendo denominada Escola Estadual Indígena de Ensino Fundamental Gatén, porém, ainda não está funcionando, de modo que há neste momento cerca de vinte crianças Kaingang estudando na escola Manuel Bandeira (E1 - 23/10/2015).

Já a Terra Indígena Pó Mág, localizada em Tabaí, vem enfrentando desde sua criação, resistência por parte da sociedade envolvente no que diz respeito às 
suas demandas por acesso à educação e também a saúde. Um tipo de reação que também ocorrera em relação às terras indígenas Foxá e Jamã Tü Tãnh, uma vez que essas comunidades da mesma forma sofreram e ainda sofrem o descaso e o desrespeito aos seus direitos constitucionais.

Não há abastecimento de água na Terra Indígena Pó Mág, de modo que os antigos proprietários da área se utilizavam de um poço artesiano para obtê-la. No entanto, no momento da instalação da comunidade Kaingang no local, este poço já estava inutilizado, sem os instrumentos mecânicos necessários para a obtenção da água. A liderança da época, o cacique Francisco Rockãa, informa ter tentado resolver a questão a partir da obtenção de uma nova bomba d'água, porém sem auxílio dos órgãos competentes como a Secretária de Saúde Indígena (SESAI), não obteve sucesso (DIÁRIO de Campo, 11/09/2014).

Em relação à educação, desde o estabelecimento da comunidade em fins do ano de 2013, que o então cacique Francisco Rockã vinha buscando matricular as crianças indígenas no sistema escolar local gerenciado pela Secretária de Educação do município, porém não obteve sucesso (DIÁRIO de Campo, 08/01/2014). As sucessivas negativas da matrícula escolar das crianças levaram a comunidade Kaingang a acionar o Ministério Público Federal (MPF) por meio do Termo de Declarações PR-RS - 00014694/2014, que se encontra presente no Procedimento Preparatório $\mathrm{n}^{\mathrm{o}}$ 1.29.000.002074/2014-11 (BRASIL, 2014). Segundo a referida documentação, a liderança Kaingang foi informada que as matrículas não poderiam se efetivar devido à "suposta incompatibilidade curricular", ou seja, algo completamente descabido em decorrência do fato que a maioria das crianças da comunidade frequentava anteriormente, uma escola não indígena em Lajeado.

Nesse mesmo documento, a comunidade solicita a contratação de um professor indígena, no sentido de resolver a questão sem maiores conflitos. Além disso, o MPF e a FUNAI também ratificam que o problema deveria ser resolvido o mais rápido possível.

Frente a isso, a situação foi novamente encaminhada ao MPF de Porto Alegre, através do Ofício 44/CTL POA/2014, onde a comunidade da Pó Mág relata "diversas formas de preconceito por parte do Poder Público Municipal, principalmente no que diz respeito à questão da educação". No referido ofício é solicitado um diálogo entre a Coordenadoria Regional de Educação (CRE), a FUNAI e o MPF com a prefeitura local e suas secretárias, pelo fato de alegarem não poder matricular os alunos indígenas devido à disparidade em relação a faixa etária dos mesmos. Essa informação é confirmada pelo entrevistado E1 (2015), que atua junto a $3^{\mathrm{a}} \mathrm{CRE}$, conforme segue:

Eles tiveram resistência em Tabaí. Tabaí se explicou quando eles estiveram em 2014, no segundo semestre eles foram no Ministério Público e Tabaí negou vaga, realmente eles confirmaram que fizeram isso diante do Ministério Púbico porquê... pelo seguinte, eles falaram que não tinha como colocar uma criança de quinze, catorze com crianças de oito. Mas na verdade tinha outras crianças com a mesma idade né, pequenos. Então foi uma justificativa que deixou a desejar, pelo menos os pequenos podiam ser incluídos e aí eles falaram que 
transporte, que é demanda do município, como é que o transporte ia entrar lá em cima, não tinha como da BR, porque eles moram em um local de difícil acesso, bem irregular assim. Então eles alegaram isso né, que não teria como o transporte ir buscar lá dentro e também colocar um aluno grande com um aluno pequeno. Eles alegaram que não negaram a vaga, mas como justificativa colocaram isso (E1 - 23/10/2015, p. 4 - 5).

A ação empreendida pela Terra Indígena Pó Mág foi acompanhada pelas outras comunidades que através do cacique Valdomiro Vergueiro da Terra Indígena Morro do Osso/Porto Alegre, solicitaram uma reunião no MPF para discutir questões relacionadas à educação e saúde nas terras indígenas localizadas nos municípios de Lajeado, Estrela, Tabaí, São Leopoldo e Farroupilha. Nesta reunião, a liderança exigiu a solução dos problemas enfrentados pela Terra Indígena Pó Mág em relação à educação e à saúde, uma vez que o abastecimento de água ainda não havia sido resolvido àquela altura, solicitando auxílio da SESAI na resolução da questão, assim como dos órgãos referidos anteriormente (BRASIL, 2014).

No dia 19 de agosto de 2014, a comunidade da Terra Indígena Pó Mág redigiu uma carta endereçada ao Procurador do MPF de Porto Alegre, Sr. Mauro Cichowski dos Santos, onde expunham o problema e a não resolução do mesmo por parte dos órgãos públicos, além de apresentar uma imagem do açude, quase seco e cuja água era imprópria para o consumo e que, no entanto, estava sendo consumida pela comunidade, conforme trecho a seguir:

Nós Kaingang da Terra Indígena Pobán, localizada no município de TabaíRS, viemos através deste documento pedir ajuda em uma questão de extrema urgência. Desde o final de 2013 ocupamos a área em que vivemos e desde lá enfrentamos sérios problemas divido à falta de água. O verão passado foi um dos mais quentes dos últimos anos e nós vivemos esse período praticamente sem ter água potável (CARTA, 2014, p. 1).

Em resposta às solicitações da comunidade, o MPF se reuniu com os gestores públicos envolvidos na questão, estando eles situados no âmbito municipal, estadual e federal. No termo de reunião, registrado no Procedimento Preparatório $\mathrm{n}^{\circ}$ 1.29.000.002074/2014-11, a SESAI se prontificou a tomar as providencias cabíveis no sentido de propiciar o abastecimento de água para a comunidade, emergencialmente através de uma caixa d'água abastecida a partir de um caminhão pipa (BRASIL, 2014).

Os órgãos públicos da esfera municipal por sua vez, através de seus representantes, informaram que o motivo dos desencontros em relação ao atendimento escolar, bem como da saúde, foi a não comunicação prévia do deslocamento daquela comunidade Kaingang para o município de Tabaí, motivo pelo qual não estariam preparados para recebê-los. Entretanto, tal justificativa foi refutada pela Secretária Especial de Saúde Indígena (SESAI) que reiterou ter oferecido informações à prefeitura local e que estava sozinha no cumprimento destas funções, as quais deveriam ser realizadas através da parceria entre este órgão estadual e a Secretaria de Saúde municipal. A prefeitura de Tabaí, nesta mesma reunião, questionou a aquisição da área de terra onde está inserida a Pó Mág, 
indagando a possibilidade de superfaturamento no processo de compra daquela terra (BRASIL, 2014).

Desse modo, a SESAI se comprometeu o disponibilizar o mais rápido possível, o incentivo estadual para a saúde indígena. $\mathrm{O}$ incentivo em questão consta na Portaria estadual $\mathrm{n}^{\circ} 41 / 2013$ publicada no Diário Oficial de $1^{\circ}$ de fevereiro de 2013 do estado do Rio Grande do Sul, que garante uma verba de quatro mil reais a municípios que possuírem uma Equipe Multidisciplinar de Saúde Indígena (EMSI) ${ }^{8}$, ou como no caso de Tabaí de, no mínimo, mil reais para todo e qualquer município que possuir grupos indígenas fixados, de modo a subsidiar o atendimento médico àquela população (RIO GRANDE DO SUL, 2013). Essa verba específica está sendo enviada para o município de Tabaí, conforme aponta a entrevistada E2, onde o representante do município diz: "A gente até pediu essa verba, mas hoje a gente recebe mil reais mensal (sic) do estado, da SESAI" (E2 - 23/10/2015, p. 1).

Em relação à educação, a questão das diferenças na faixa etária foi novamente referida pelo município de Tabaí para a não matrícula das crianças indígenas. Em resposta, a Secretária de Educação (SEDUC) do estado informou que inicialmente a implantação de uma escola indígena na área era inviável devido ao fato de haver apenas três crianças em idade escolar naquele momento (final de 2013 e início de 2014), mas que a SEDUC já estava a par de que a população da comunidade havia aumentado, de modo que a criação e instalação de uma escola na Terra Indígena Pó Mág deveria tramitar até o fim do ano de 2014.

Após a reunião e a não resolução imediata dos problemas, a comunidade foi forçada mais uma vez a se reunir junto ao MPF de Porto Alegre no dia 25 de setembro. Representando a comunidade estavam presentes o então cacique Francisco Rockãa, sua esposa Lurdes Carvalho e o então vice cacique da Pó Mág, Tomé Fongue, com o objetivo de alcançar a imediata normalização do acesso à saúde e educação na comunidade. O problema foi resolvido no mês de outubro de 2014, quando houve finalmente a instalação de uma caixa d'água na comunidade, fato que fora muito comemorado. Esta primeira caixa, segundo informações do Diário de Campo (23/10/2015), foi substituída posteriormente por outra, mais resistente, sendo abastecido a cada quinze dias por um caminhão pipa enviado pela SESAI, ou quando não há mais água.

No entanto, os problemas persistiram. O acesso do caminhão à Terra Indígena Pó Mág é dificultado pela localização da mesma, já que se trata de uma área de acentuado aclive conforme atesta levantamento topográfico do local conseguido junto ao SEDUC, além das péssimas condições da estrada. Devido a isso, algumas vezes o caminhão não consegue abastecer a comunidade dentro do prazo estipulado.

8 Programa do Ministério da Saúde voltado para facilitar e garantir o atendimento das populações indígenas pelo Sistema Único de Saúde (SUS). 
Uma nova reunião no MPF ocorreu no dia trinta de julho de 2015, onde o então vice cacique Tomé Fongue se reuniu com representantes da SESAI, da Companhia Rio-Grandense de Saneamento (CORSAN). A presença da CORSAN foi uma solicitação da SESAI, que devido à ineficiência do abastecimento a partir do caminhão pipa, cogitava-se a perfuração de um novo poço artesiano, questão que caberia então a este órgão. Os estudos de viabilidade da perfuração seriam solicitados à prefeitura municipal (BRASIL, 2014).

No mês de novembro de 2014, o MPF solicitou informações por parte da SEDUC e da SESAI sobre como andavam os encaminhamentos para a instalação da escola indígena na Pó Mág, bem como a respeito do atendimento médico da comunidade, uma vez que havia sido prometido pelos seus representantes a regularização da situação até o final daquele ano. Isto é possível verificar em documentação encaminhada à SEDUC, conforme segue:

Durante a tramitação do referido inquérito civil, mais especificamente no dia 10 de setembro de 2014, foi realizada reunião, oportunidade em que Vossa Senhoria afirmou que, em face do aumento do número de crianças e jovens na aldeia Kaingang de Tabaí/RS, é o caso de ser implantada uma escola indígena no local, sendo "que dará início às providências necessárias para tanto; que o processo de criação da escola indígena deverá tramitar junto ao Conselho Estadual de Educação até o final de 2014, para que, após aprovada, seja publicado o decreto de criação pelo Governador do Estado; que provavelmente no início de 2015 será aberto o cadastro para contratação temporário de professor e merendeira indígenas; que também ficará para o início do ano de 2015 a celebração de convênio entre o Município de Tabaí/ RS e o Estado do Rio Grande do Sul para viabilização do transporte aos alunos indígenas dos anos finais do ensino fundamental" (BRASIL, 2014, sem número de página).

Buscando auxiliar na resolução da questão da escola, a própria comunidade da Pó Mág buscou um professor que posteriormente seria oficializado pela $3^{a}$ CRE. Desse modo, uma professora, oriunda da Terra Indígena de Guarita, se estabeleceu em Tabaí em fins de 2014 e permaneceu na mesma até meados do ano de 2015 ministrando aulas de forma voluntária. Entretanto, devido à falta de perspectiva de regularização de sua situação e pelo fato de não ter o curso de magistério concluído, a referida professora retornou para sua comunidade de origem (DIÁRIO de Campo, 23/10/2014; 28/05/2015).

Finalmente em treze de março de 2015, a criação da escola foi confirmada por meio de publicação no Diário Oficial do estado do Rio Grande do Sul, sendo denominada Escola Estadual Indígena de Ensino Fundamental Pó Mág, visando a atender as treze crianças da comunidade, cuja faixa etária estendia-se entre os seis e os catorze anos. No entanto, apesar da criação e nominação da escola, de concreto não houve maiores avanços, conforme relato do entrevistado E1 (2015):

[...] Na verdade o estado deveria ter já dado uma urgência para esse caso, porém houve, bem na época, a troca de governo. Quando eles foram no Ministério Público a segunda vez, a segunda vez foi esse ano, mas quando eles foram em 2014, já estava sendo feito encaminhamento, foi feito encaminhamento aqui 
na CRE tava [sic] sendo feito o encaminhamento para que fosse aprovado pelo estado a criação, a primeira coisa que é feito e a criação e denominação da escola depois o processo de credenciamento e autorização. Daí como foi exigido aqui da CRE, a CRE fez isso, a CRE encaminhou só que daí até o final do ano esse encaminhamento não obteve resposta entenderam, foi feito o oficio, mais de um oficio inclusive, feito pra que fosse feito [alarme de carro tocando] criada a denominação da escola. Então só em março desse ano o governo Sartori assinou (E1 - 23/10/2015, p. 6).

Um novo professor chegou à Terra Indígena Pó Mág em meados do ano de 2015 convidado pelas lideranças locais. Também oriundo da Terra Indígena de Guarita, o professor iniciou de maneira voluntária as aulas, aguardando sua contratação e regularização pelo estado. Como a situação persistiu, a alternativa encontrada pela comunidade indígena foi a de ministrar as aulas na garagem de uma das moradias da Terra Indígena Pó Mág, que pertencia aos antigos moradores da área (DIÁRIO de Campo, 28/05/2015).

A escola Pó Mág, quando em funcionamento, seguirá assim como as demais escolas indígenas Kaingang, o regimento educacional próprio, estabelecido pelo Parecer $n^{\circ}$ 06/2003 da Comissão de Ensino Fundamental (RIO GRANDE DO SUL, 2003). Este regimento apresenta como objetivos e finalidades da escola indígena Kaingang a formação básica, diferenciada e de qualidade, enfatizando a continuidade linguística e cultural do grupo, conforme segue:

Essa escola é um instrumento de conscientização na comunidade para evitar a perda cultural e linguística. Nesse sentido, realiza o resgate cultural da identidade étnica e da língua indígena por meio do incentivo às práticas tradicionais, às crenças, aos usos e costumes, às festividades de datas significativas, à língua e às tecnologias indígenas, valorizando e difundindo a cultura Kaingang (RIO GRANDE DO SUL, 2003, p. 3).

De qualquer modo, o imbróglio pela instalação da escola na Terra Indígena Pó Mág prosseguiu, mesmo tendo seu funcionamento praticamente acertado juridicamente. Na primeira semana do mês de julho de 2015, a SEDUC abriu edital para a contratação de professores indígenas, buscando regularizar a situação das escolas indígenas, não só na região do Vale do Taquari, mas também em outras partes do estado. A comunidade aguardava havia muito a abertura de tal edital por parte da SEDUC, pois se pretendia regularizar a situação do professor indígena que já estava estabelecido no local (DIÁRIO de Campo, 18/09/2015).

Sobre isto, apresenta-se seguinte relato:

Tabaí é assim, nós mandamos ontem né, foi levado o processo daqui da coordenadoria de várias páginas pra Porto Alegre e esse processo foi pra SEDUC e pro Conselho Estadual de Educação sendo que neste processo consta uma ata do Ministério Público onde dois anos as crianças ficaram sem escola né e as crianças precisam estudar, isto está na lei, é obrigatório e está sendo uma falha né essas crianças estarem fora da escola. Então foi em agosto desse ano que eles foram no Ministério Público dizer isso, que eles não queriam mais que as crianças ficassem sem escola. A comunidade indígena exigiu que essas crianças frequentassem uma escola ou que as 
crianças fossem... eles queriam uma escola na área indígena né, porque ali naquela área da pra se construída. Aí aconteceu em março desse ano, [alarme de carro tocando] treze de março de 2015 que o governo do estado assinou o decreto de criação e denominação da escola. Esse ano ele criou e assinou esse decreto no diário né. Aí essas crianças, são doze crianças que estão fora da escola desde dezembro, desde o segundo semestre de 2013, quando eles se mudaram pra lá, então na verdade há dois anos eles estão fora da escola (E1 - 23/10/2015, p. 3 - 4).

A burocracia é um dos grandes entraves para a não consolidação da escola indígena na Terra Indígena Pó Mág, que há dois anos vem nesta caminhada para a implantação deste direito constitucional. As várias instâncias pelas quais este tipo de demanda deve transitar foram responsáveis por postergar a implantação da escola para o ano letivo de 2016. Desse modo temos:

Então agora a gente conseguiu instaura esse processo, enviando pra SEDUC e pro conselho estadual de educação, e aí eles analisam esse processo e algumas coisas que tem que ser, como vou dizer assim, algumas coisas que eles percebam que não está adequado, retorna pra nós, por exemplo, as fotos, fotos não pode ter pessoas, tem que ser só as instalações. Nós tiramos fotos assim com alguns indígenas daí não pode né. Então a gente vai refazer as fotos e a gente vai estar enviando esse processo para que eles tenham escola. E tem um professor já em vista que é um professor lá do norte também, parente da liderança da aldeia Pó Mág de Tabaí. Esse professor é bem jovem, Mizael Carvalho. Então ele se formou em estudo bilíngue na escola de São Valério, na mesma escola que o outro professor. Ele se formou na escola bilíngue e então ele vai lecionar o Kaingang e também o currículo por atividades ali naquela escola. Só que nós só chamaremos ele em um momento posterior, agora tem que esperar esse processo porque tem toda uma burocracia para aguardarmos, porque a gente gostaria que ele assumisse ontem (E1 - 23/10/2015, p. 4).

A construção da escola na Terra Indígena Pó Mág prevista nas medidas compensatórias da duplicação da BR 386, deverá levar em consideração aspectos próprios da cultura Kaingang, a exemplo do que está acontecendo na Terra Indígena Jamã T̈̈ Tãnh onde o prédio da futura escola apresenta as marcas exogâmicas Kamé e Kairu. A representante da $3^{a}$ CRE entrevistada para o presente estudo confirma isso, bem como demonstra ter conhecimento sobre o assunto:

Secretária de Obras no caso é estudado junto né, Secretária de Obras e Secretária de Educação. A gente tem visto, por exemplo aqui em Estrela, a construção foi de acordo com a cultura indígena né, tem sido feito de acordo com a cultura indígena que é os dois irmãos mitológicos, Kamé e Kairu, que foi feito ali, muito bonito o projeto. A gente espera que seja feito a partir da cultura indígena os demais já que ali foi um modelo, muito lindo, muito significativo dessa cultura. A gente espera que seja construída assim, porque no norte não é assim, nas demais escolas que já tem os indígenas que tem outras escolas indígenas que não foi construído dessa forma. Mas que isso seja um modelo e que provavelmente isso vai ser cumprido porque agora as comunidades indígenas viram que fico. Todos eles quando visitam ali dizem, nós queremos que nossa escola fique assim também, tem a ver com a nossa cultura". Então eu acredito de acordo com que a comunidade deseja que também vai ser feito assim dessa forma. Eu acredito que sim, que vai ser de 
acordo com a cultura deles. Porque o que eles reivindicam, normalmente eles são atendidos, as vezes um pouco devagar, mas enfim (E1 - 23/10/2015, p. 7).

Além da regularização do abastecimento de água para a comunidade, a Terra Indígena Pó Mág vinha enfrentando resistência por parte do município de Tabaí também no âmbito do atendimento médico, conforme abordado. No entanto, esse quadro parece ter sido resolvido nos meses iniciais do ano de 2015, uma vez que as famílias Kaingang passaram a ser atendidas no posto de saúde local, conforme relata o novo cacique, Tomé Fongue, ao informar que a comunidade estava sendo bem atendida pelo posto de saúde local, diferentemente do que ocorria logo após instalarem-se em Tabaí, sendo esta uma conquista importante para a Terra Indígena Pó Mág (DIÁRIO de Campo, 18/09/2015).

Conforme relato do entrevistado E2 (2015) sobre o atendimento médico na comunidade da Pó Mág, temos:

Eles são atendidos aqui mesmo (posto de saúde) pelo dentista, pelos médicos da atenção básica e eles têm visita domiciliar que o médico vai até a aldeia com a enfermeira e a agente deles também. [...] é um médico do Saúde da Família que faz visita lá, com a nossa enfermeira. Que a equipe faz visita domiciliar. [...] eles atendem a área indígena e os demais bairros que pertencem pra área deles, que seria o SF1, que seria o médico do Saúde da Família (E2 30.10.2015, p. 3).

Tal fato pode ser exemplificado pelo falecido cacique Francisco Rockãa, que teve seu tratamento garantido pela saúde local em relação a uma tuberculose e posteriormente um câncer no pulmão. No entanto, devido à gravidade do seu quadro de saúde, Francisco precisou ser transferido para Porto Alegre, aonde veio a falecer (DIÁRIO de Campo, 28/05/2015; 25/06/2015).

Quando perguntada sobre qual tipo de atendimento era mais comum entre a comunidade, o entrevistado E2 (2015) apontou o caso do falecido cacique Francisco como excepcional, uma vez que a comunidade dificilmente procura o atendimento. Sobre isto, temos:

[...] eles não procuram muito não. É só quando realmente eles têm necessidade, eles não têm como vir assim periodicamente fazer exames esse tipo de coisa, acompanhamento só que seja realmente necessário, se é um caso especifico, como o cacique deles lá9 que teve um caso de tuberculose e nos procurou, foi atendido, medicado e então ele vinha todo mês. Que até ele veio a falecer faz uns três meses já, por motivo, mas daí de câncer, ele morreu de câncer de pulmão (E2 - 30/10/2015, p. 1-2).

A relação entre comunidade da terra indígena e os responsáveis pelo atendimento médico é positiva segundo afirma um membro da comunidade:

9 O entrevistado E5 está se referindo ao cacique Francisco Rockã dos Santos. 
Bem tranquila... Eles têm uma agente de saúde que trabalha conosco aqui, integrada na rede da atenção básica e eles procura... toda vez que eles procuram nós aqui são atendidos, não tem reclamação, bem tranquilo. [...] é bem tranquilo, eles procuram quando eles têm alguma demanda assim específica deles, alguma dor, alguma coisa. Só nesses casos mesmo eles procuram a saúde (E2 - 30/10/2015, p. 1).

Outra conquista empreendida pela terra indígena e sua liderança foi a contratação de maneira emergencial, por parte da SESAI, de um membro da comunidade como agente de saúde indígena, visando a suprir as necessidades médicas da comunidade, recebendo do órgão treinamento e aperfeiçoamento para cumprir esta função. A referida agente, denominada aqui de entrevistado E3 comenta que: "Aqui é coisa de todo dia que eu acompanho. Todo dia que eu estou assim nas casas, mas só que assim, eu anoto só uma vez por semana" (E3 23/10/2015, p. 1).

Mesmo hoje, com a escassez de produtos naturais, a comunidade ainda busca se utilizar de remédios do mato a partir dos conhecimentos dos mais velhos, mesmo que em menor quantidade que nos tempos de outrora, conforme segue: "Assim, minha mãe, por exemplo, quando a gente fica doente, ela procura os remédios assim no mato. Mas daí eu não sei te dizer bem o nome porque só ela que sabe" (E3 - 23/10/2015, p. 1).

Como visto, apesar dos percalços iniciais, as demandas da comunidade Kaingang da Terra Indígena Pó Mág vêm aos poucos sendo alcançadas, e conquistas importantes já aconteceram como o acesso indiscriminado da comunidade ao sistema de saúde local, a contratação de uma agente de saúde indígena e a criação e denominação de uma escola indígena a ser construída dentro daquela área, entre outras. Percebe-se, dessa maneira, que a luta e o protagonismo dessa população pela obtenção e pela garantia de seus direitos vem sendo construída pouco a pouco, com esforço e dedicação.

\section{Consideraçóes Finais}

Conforme apresentado, as populações indígenas, entre elas os Kaingang, possuem suas próprias concepções de educação e saúde, intrínsecas entre si e advindas da transmissão oral a partir de seus ancestrais. Ao longo do processo do contato com os não indígenas, no entanto, houve uma tentativa de impor os ideais próprios da sociedade ocidental às populações indígenas através da educação escolarizada, seja ela de cunho religiosa ou laica, visando levar essas populações aos padrões entendidos como "civilizados".

Dessa maneira, percebe-se a inserção da Terra Indígena Pó Mág no longo processo de lutas Kaingang advindas desde os primeiros contatos com o elemento não indígena até o processo de reterritorialidade, marcado pelas difíceis relações com as populações não indígenas. Além disso, a luta Kaingang da Terra Indígena Pó Mág, assim como das demais terras indígenas da bacia Taquari-Antas, também se desenvolve no que diz respeito a sua manutenção cultural a partir do acesso a 
uma saúde e educação diferenciada, que leve em consideração sua alteridade étnica e seus saberes tradicionais, sendo esta considerada também como uma demanda central dessa população na busca pela sua continuidade étnica demonstrando sua preocupação em afirmar-se como identidade própria.

A Constituição Federal de 1988 apresentou para as populações indígenas novas possibilidades em relação à reprodução de seus processos próprios, questão essa que se dá a partir do reconhecimento da importância da língua nativa e de sua manutenção a partir de escolas dentro das terras indígenas. A partir disso uma série de medidas governamentais no âmbito da educação escolar indígena vem surgindo, visando avançar ainda mais nesta questão. A conquista de espaços como este, assim como a garantia de seus direitos em relação ao acesso à saúde pública, no entanto, ainda é realidade distante em alguns casos, mas a partir do protagonismo das comunidades Kaingang e suas lideranças, essas demandas vêm sendo alcançadas nas terras indígenas localizadas em áreas da bacia hidrográfica Taquari-Antas.

A Terra Indígena Pó Mág, foco do presente estudo, desde sua instalação na área em fins do ano de 2013 tem lutado pelas demandas que lhes são garantidas. Salienta-se que embora gradativo, percebe-se que a comunidade através de suas lideranças vem conquistando avanços importantes, contrastando com o cenário inicial, momento em que sequer eram reconhecidos pelo poder público local, envolto em um misto de preconceito e desconfiança. A contratação de uma agente de saúde local e a contratação de um professor indígena por parte da SEDUC para atuar na comunidade demonstram o protagonismo Kaingang na obtenção e manutenção de seus direitos, na busca pela sua continuidade histórica e cultural.

\section{REFERÊNCIAS}

ALMEIDA, Ledson Kurtz; FERNANDES, Ricardo Cid (org.) Programa de apoio as comunidades Kaingangs - Plano básico ambiental das obras de duplicação da Rodovia BR-386 - segmento 350,8 - Km 386,0, com 35,2 km de extensão. MRS Estudos Ambientais LTDA: 2010.

AQUINO, Alexandre Mágno. Ën Ga Vyg ën Tóg “nós conquistamos nossas terras”: Os Kaingang no litoral do Rio Grande do Sul. Brasília-DF. 2008. 214f. Dissertação (mestrado) - Universidade de Brasília. Brasília-DF, 2008.

BANIWA, Gersem. Os desafios da educação indígena intercultural no Brasil: avanços e limites na construção de políticas públicas. In. NÖTZOLD, Ana Lúcia Vulfe; ROSA, Helena Alpini; BRINGMANN, Sandor Fernando (Org.). Etnohistória, história indígena e educação: Contribuições ao debate. Porto Alegre-RS: Palotti, 2012. p. 69-88.

BARTH, Fredrik. Os grupos étnicos e suas fronteiras. In. O guru, o iniciador e outras variações antropológicas. Rio de Janeiro-RJ: Contra Capa Livraria, 2000. p. 25-67.

BERGAMASCHI, Maria Aparecida; MEDEIROS; Juliana Schneider. História, memória e tradição na educação escolar indígena: o caso de uma escola Kaingang. Revista

Brasileira de História. São Paulo-SP, v. 30, nº 60, p. 55-75, 2010. 
BRASIL. Constituição (1988). Constituição da República Federativa do

Brasil. Disponível em: <http://www.planalto.gov.br/ccivil_03/constituicao/ constitui\%C3\%A7ao.htm>. Acesso em: 01 ago. 2015.

BRASIL. Ministério Público Federal no Rio Grande do Sul. Procedimento Preparatório $n^{\circ}$ 1.29.000.002074/2014-11. Porto Alegre-RS, 2014.

BRINGMANN, Sandor Fernando. O programa educacional do SPI e os clubes agrícolas escolares: a experiência entre os Kaingang do RS e de SC (1941 - 1967). In. NÖTZOLD, Ana Lúcia Vulfe; ROSA, Helena Alpini; BRINGMANN, Sandor Fernando (Org.).

Etnohistória, história indígena e educação: Contribuições ao debate. Porto AlegreRS: Palotti, 2012. p. 123-147.

BUGRES estiveram em Cruzeiro. O Informativo do Vale, p. 09, Lajeado-RS, 27 de ago. 1978.

CARTA ao Senhor procurador do Ministério Público Federal. Comunidade Kaingang Pedra Grande, Tabaí-RS: agosto de 2014. In. BRASIL. Ministério Público Federal no Rio Grande do Sul. Procedimento Preparatório n ${ }^{\mathbf{0}}$ 1.29.000.002074/2014-11. Porto AlegreRS, 2014.

CENSO DEMOGRÁFICO 2010. Instituto Brasileiro de Geografia e Estatísticas (IBGE). Rio de Janeiro: IBGE, 2011. Disponível em: <http://censo2010.ibge.gov.br/>. Acesso em: set. 2015.

CLASTRES, Pierre. A sociedade contra o Estado. Porto-POR: Afrontamento, [1974] 1979.

Arqueologia da violência - pesquisas de antropologia política. São Paulo-SP: Cosac Naify, [1980] 2014.

CULTURA da sobrevivência: Indígenas que estão pelas ruas são protegidos por lei. Fato Novo, Montenegro-RS, 07 de out. 2015.

DIÁRIO de Campo de 08/01/2014. Visita à Terra Indígena Pó Mág no Vale do Taquari. Projeto de 08 jan. 2014.

$4 \mathrm{p}$.

DIÁRIO de Campo de 20/05/2014. Visita à Terra Indígena Foxá e Pó Mág no Vale do Taquari. Projeto de 20 mai. 2014. 5 p.

DIÁRIO de Campo de 11/09/2014. Visita à Terra Indígena Pó Mág no Vale do Taquari. Projeto de 11 set. 2014.2 p.

DIÁRIO de Campo de 23/10/2014. Visita à Terra Indígena Pó Mág no Vale do

Taquari. Projeto de 23 out. 2014.2 p.

DIÁRIO de Campo de 28/05/2015. Visita à Terra Indígena Pó Mág no Vale do Taquari. Projeto de 28 mai. 2015. 4 p.

DIÁRIO de Campo de 25/06/2015. Visita à Terra Indígena Pó Mág no Vale do Taquari. Projeto de 25 jun. 2015.6 p. 
DIÁRIO de Campo de 18/09/2015. Visita à Terra Indígena Pó Mág no Vale do Taquari. Projeto de 18 set. 2015.2 p.

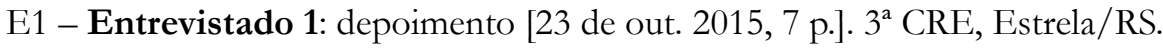
Entrevistador: Jonathan Busolli. Estrela (RS): s.e., 2015. Gravação em máquina digital. Entrevista concedida ao Projeto de Extensão História e Cultura Kaingang em Territórios da Bacia Hidrográfica Taquari-Antas. Lajeado: Univates.

E2 - Entrevistado 2: depoimento [30 de out. 2015, 3 p.]. Secretaria de Assistência Social, Tabaí/RS. Entrevistador: Jonathan Busolli. Tabaí (RS): s.e., 2015. Gravação em máquina digital. Entrevista concedida ao Projeto de Extensão História e Cultura Kaingang em Territórios da Bacia Hidrográfica Taquari-Antas. Lajeado: Univates.

E3 - Entrevistado 3: depoimento [23 de out. 2015, 2 p.]. Agente de saúde indígena, Terra Indígena Pó Mág, Tabaí/RS. Entrevistadores: Emeli Lappe e Jonathan Busolli. Tabaí (RS): s.e., 2015. Gravação em máquina digital. Entrevista concedida ao Projeto de Extensão História e Cultura Kaingang em Territórios da Bacia Hidrográfica TaquariAntas. Lajeado: Univates.

ESTATÍSTICAS da Secretária Estadual de Educação do Rio Grande do Sul. Disponível em: <http://www.educacao.rs.gov.br/pse/html/estatisticas.jsp?ACAO=acao1 $>$ Acesso em: 26/11/2015.

FARIA, André. A visão do jornal O Informativo do Vale de Lajeado-RS sobre a duplicação da BR-386 entre janeiro e julho de 2014. 2014. 67 f. Lajeado-RS: Monografia (Graduação) - Curso de História, Centro Universitário Univates, 2014. GONÇALVES, Jaci Rocha. Relatório final antropologia na área de duplicação da BR 386, Triunfo, Tabaí, Taquari, Fazenda Vila Nova, Bom Retiro do Sul e Estrela - RS Aldeia Kaingang TI Estrela. Tubarão-SC: Universidade do Sul de Santa Catarina - UNISUL - 2008.

GONÇALVES, Lylian Mares Cândido. Crianças indígenas Kaingang em escola não indígena: um estudo de caso envolvendo a Escola Estadual de Ensino Fundamental Manuel Bandeira, em Lajeado/RS. 2011. 74 f. Monografia (Pós-Graduação) Especialização em Supervisão e Gestão Educacional, Centro Universitário UNIVATES, Lajeado-RS, 2011.

JÚNIOR, Danton; ODY, José. Faxinalzinho Um Ano Depois. Correio do Povo, Porto Alegre-RS, 26 de abr. de 2015.

LAJEADO. (município). Lei $\mathbf{n}^{\mathbf{0}} \mathbf{8 . 0 5 3}$, de 13 de agosto de 2008. Lajeado-RS: 13 de ago. 2008, fotocópia. 2 p.

LAPPE, Emeli; LAROQUE, Luís Fernando da Silva. Um estudo sobre indígenas Kaingang em áreas urbanas no Rio Grande do Sul. História e-História. CampinasSP. v. 00, n. 00 set. 2013. Disponível em: < http://historiaehistoria.com.br/materia. cfm?tb=artigos\&id=246>. Acesso em: 27 de set. 2013.

LAROQUE, Luís Fernando da Silva. Os Kaingangues: Momentos de Historicidade Indígenas. In. BOEIRA, Nelson; GOLIN, Tau. (Org.). Povos indígenas - Volume 
5. Passo Fundo-RS: Méritos Editora, 2009. p. 81-108. (Coleção: História Geral do Rio Grande do Sul).

MATTTE, Dulce Claudete. Indígenas no RS: educação formal e etnicidade. In. SILVA, Gilberto Pereira da; PENNA, Rejane; CARNEIRO, Luiz Carlos da Cunha (Org.). RS índio: cartografias sobre a produção do conhecimento. Porto Alegre-RS: EDIPUCR, 2009, p. 104-114.

NOBRE, Domingos. História da Educação Escolar Indígena no Brasil. In. Escola Indígena Guarani no Rio de Janeiro na Perspectiva da Autonomia: Sistematização de Uma Experiência de Formação Continuada. Tese de doutorado. Universidade Federal Fluminense. Niterói-RJ, p. 1-19, 2005.

NONNENMACHER, Marisa Schneider. Aldeamentos Kaingang no Rio Grande do Sul (século XIX). Porto Alegre-RS: EDIPUCRS, 2000.

OFÍCIO 44/CTL POA/2014. In. BRASIL. Ministério Público Federal no Rio Grande do Sul. Procedimento Preparatório n ${ }^{\mathbf{0}}$ 1.29.000.002074/2014-11. Porto Alegre-RS, 2014.

OFÍCIO Nº 615/2014/PRES/FUNAI. In. BRASIL. Fundação Nacional do Índio (FUNAI). MJ - No 08620.000719/2008-1. 2008. 2014b.

OLIVEIRA, Marilda Dolores. Essa terra já era nossa: um estudo histórico sobre o grupo Kaingang na cidade de Lajeado. 2010. 89 f. Lajeado-RS: Monografia (Graduação) Curso de História, Centro Universitário Univates, 2010.

RIO GRANDE DO SUL (estado). Secretária de Educação. Parecer n $\mathbf{0}^{\mathbf{6}} \mathbf{2 0 0 3}$ Comissão de Ensino Fundamental. Porto Alegre-RS: 8 de jan. 2003.

ROSA, Alexandre Nunes. Estudo de impacto ambiental das obras de duplicação da rodovia BR-386/RS trecho: Entr BR-158(A) (Div SC/RS) - Entr BR-116 (B)/290 (Porto Alegre), subtrecho: Entr BR-453/RS-130 (P/ Lajeado) - Entr BR-287(A) (Tabai), Segmento: Km 350,8 - Km 386,0, Com 35,2 Km de extensão. Brasília-DF: DNIT, 2011.

SALDANHA, Jose R. “Eu não sou pedra para sempre”: Cosmopolítica e espaço Kaingang no sul do Brasil meridional. Porto Alegre-RS. 2009. 208 f. Dissertação (mestrado) - Programa de Pós-Graduação em Antropologia Social - Universidade Federal do Rio Grande do Sul. 2009.

SALVARO, Talita Daniel. O ensino aprendizagem da língua Kaingáng como fator de identidade. In. NÖTZOLD, Ana Lúcia Vulfe; ROSA, Helena Alpini; BRINGMANN, Sandor Fernando (Org.). Etnohistória, história indígena e educação: Contribuições ao debate. Porto Alegre-RS: Palotti, 2012. p. 149-161.

SEEGER, Anthony; CASTRO, Eduardo B. Viveiros. Terras e Territórios Indígenas no Brasil. Encontros com a Civilização Brasileira. Rio de Janeiro-RS, 1979. p.101-109.

SILVA, Juciane Beatriz Sehn da. Territorialidade Kaingang: um estudo da aldeia Kaingang Linha Glória, Estrela -RS. 125 f. Lajeado-RS: Monografia (Graduação) - Curso de História, Centro Universitário Univates, 2011. 